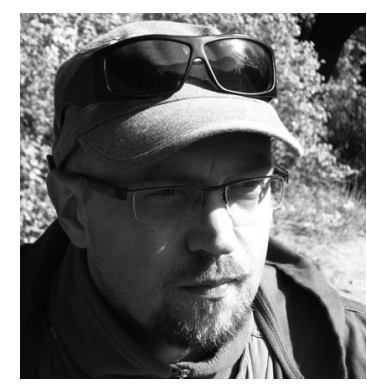

Dariusz Brzostek

Dariusz Brzostek - doktor habilitowany, adiunkt, kierownik Zakładu Antropologii Kultury w Katedrze Kulturoznawstwa Uniwersytetu Mikołaja Kopernika w Toruniu. Zajmuje się głównie antropologią literatury, twórczością Stanisława Lema oraz studiami kulturowymi (pogranicza artystycznej awangardy, teoria improwizacji etc.), a także krytyką literacką i muzyczną. Publikował teksty naukowe i eseistyczne na łamach „Tekstów Drugich", „Literatury Ludowej”, „Polonistyki", "Anteny Krzyku”, "Ha!artu”, "Glissanda”, "Opcji" oraz magazynu "Fragile". Wydał monografię Literatura i nierozum. Antropologia fantastyki grozy (2009). 


\section{Corpus eroticum albo fantazmatyczna kochanka Jerzego Szamoty}

\section{Historia pewnej obsesji}

tatus noweli Kochanka Szamoty w dorobku artystycznym Stefana Grabińskiego oraz jego krytycznej recepcji jest dość szczególny. Pierwszy biograf i monografista twórczości autora, Artur Hutnikiewicz, zaliczył ją przed laty w poczet siedmiu arcydzieł światowej nowelistyki fantastycznej, jakie wyszły spod pióra polskiego pisarza (DO, s. 18). Sama nowela zaś doczekała się licznych świadectw odbioru oraz niejednej interpretacji literaturoznawczej, co w wypadku utworów Grabińskiego przez lata nie było, bynajmniej, regułą. Życzliwe i wnikliwe uwagi poświęcali jej Hutnikiewicz, Stanisław Lem, Krystyna Kłosińska, Robert Preus - by wspomnieć tu tylko tych kilkoro komentatorów. Zapewne też niejedno już pokolenie studentów polonistyki zmagało się z dramatycznymi losami Jerzego Szamoty w trakcie uniwersyteckich ćwiczeń z poetyki czy analizy literackiej, skupiając swą uwagę na kreacji postaci literackich, typie świata przedstawionego czy wreszcie powikłaniach anegdoty tej właśnie noweli Grabińskiego. Po cóż więc wracać raz jeszcze do skromnego rozmiarami arcydziełka lwowskiego pisarza zwanego niekiedy, nie bez powodu, „księciem polskich fantastów"?

$\mathrm{Na}$ tak sformułowane pytanie postaram się odpowiedzieć w zakończeniu podejmowanych tu rozważań. Nim to jednak nastąpi, warto przypomnieć pokrótce prostą acz wieloznaczną fabułę noweli. Kochanka Szamoty jest historią niesamowitego (w sensie freudowskim) romansu Jerzego Szamoty - skromnego recenzenta teatralnego i aktorki, Jadwigi Kalergis - nieosiągalnej dla przeciętnego śmiertelnika bogini europejskich salonów artystycznych. Znajomość - obywająca się niemal bez słów i sprowadzona w istocie swej wyłącznie do niezwykle intensywnej i namiętnej zażyłości seksualnej - trwa niespełna rok, utrzymywana, na niewyrażone wprost żądanie aktorki, w całkowitej tajemnicy przed światem. Schadzki kochanków odbywają się regularnie - co tydzień, zapowiadane niezmiennie 
lakonicznymi liścikami Jadwigi, wyrażającej gotowość przyjęcia Jerzego w swej willi - sprawiającej na mężczyźnie wrażenie całkowicie opuszczonej. Z czasem kaprysy Kalergis stają się coraz bardziej ekscentryczne - zmierzając do całkowitego ukrycia „bezcennej pychy ciała” (N, s. 395), Szamota zaś rozpoznaje niepokojące (i niesamowite!) podobieństwo nietypowych znamion: własnego oraz kochanki. Wreszcie w finałowym koszmarze erotycznym mężczyzna odkrywa, że współżyje w miłosnym zapamiętaniu z pozbawionym członków, bezgłowym korpusem - zredukowanym li tylko do kobiecego łona, obnażonego w sposób obsceniczny w całej swej bezbronności. Zakończenie utworu przynosi informację o tym, że Jadwiga Kalergis nie żyje od ponad dwóch lat. Całą opowieść poznajemy zaś dzięki pierwszoosobowej narracji samego Szamoty, ujętej w formę Kartek ze znalezionego pamiętnika, jak brzmi podtytul noweli.

Artur Hutnikiewicz, który swą monografię twórczości Grabińskiego porządkuje według motywów przewodnich jego utworów, czy też, mówiąc dokładniej, typów motywacji organizujących ich świat przedstawiony, omawia obszernie Kochankę Szamoty w rozdziale zatytułowanym znacząco Parapsychologia i spirytyzm, sytuując nowelę pośród takich dzieł, jak Szary pokój, Projekcje czy Salamandra i umieszczając ją w kontekście współczesnej Grabińskiemu mody na mediumizm, która ogarnęła nie tylko artystyczne salony, ale i naturalistycznie zorientowanych psychologów pokroju Juliana Ochorowicza. Tak postrzegany „casus Szamoty to oczywisty obłęd na tle erotycznym” (TLSG, s. 193). Co ciekawe, zdaniem Hutnikiewicza sens dosłowny noweli daje się bez trudu odczytać niejako poprzez „współczesną parapsychologię i psychopatologię”, wedle której bohater pada ofiarą „pogłębiającej się stale psychozy” (psychopatologia), będąc jednocześnie „osobnikiem wyposażonym w zdolności ideoplastyczne wysokiej mocy” (TLSG, s. 193) (parapsychologia). To zastanawiające polączenie naukowej racjonalizacji dokonywanej na mocy psychiatrycznej diagnozy z quasi-racjonalizacją motywowaną paranaukowym dyskursem spirytyzmu wydaje się w tekście literaturoznawcy dość oczywistą projekcją stanu wiedzy (para)psychologicznej współczesnej Grabińskiemu ${ }^{1}$ na procedury interpretacyjne podjęte po latach gwoli objaśnienia sensu dzieła. Tym samym Hutnikiewicz zanurza się niejako w naznaczonym spirytyzmem dyskursie psychologicznym epoki, która zrodziła Kochankę Szamoty, poszukując racjonalistycznego, naturalistycznego wyjaśnienia opisywanego fenomenu w macierzystym kontekście kulturowym dzieła. Drugim dnem utworu, jego - nacechowaną symbolicznie - wymową ideową jest zaś, zdaniem Hutnikiewicza, „uświadomienie niepokojącej dziwności życia" - ufundowanej w tym wypadku (literackim i psychopatologicznym) na tajemniczym i niejasnym związku „między niesamowitą przygodą Szamoty a tą zmarłą kobietą" (TLSG, s. 194).

W istocie kolejni interpretatorzy Kochanki Szamoty skupiali swą uwagę właśnie na zagadkowej relacji erotycznej między Jerzym Szamotą a Jadwigą Kalergis. Podążając ścieżkami wytyczonymi przez Hutnikiewicza, Robert Preus wyeksponował parapsychologiczny aspekt utworu Grabińskiego, traktując go niemal jak fabularyzowany zapis „przypadku ideoplastii materialnej” i zauważając, że autorska „orientacja w fenomenologii i fizjologii

Sama psychologia jako stosunkowo młoda dziedzina wiedzy o aspiracjach naukowych miała w owym czasie fundamentalne wątpliwości co do zakresu swych badań oraz metodologicznych kompetencji w objaśnianiu tzw. fenomenów parapsychicznych. Zob. np. S. Freud, Wykład XXX. Marzenie senne i okultyzm, [w:] idem, Wykłady ze wstępu do psychoanalizy. Nowy cykl, tłum. P. Dybel, Warszawa 1995. Wykład Freuda pochodzi z cyklu wygłaszanego w latach 1915-1917, jest więc współczesny noweli Grabińskiego opublikowanej po raz pierwszy na łamach „Pro Arte” 1919, z. 5/6 i następnie w tomie Niesamowita opowieść (1922). 
mediumizmu zbliża nowelę do rzeczowych sprawozdań licznych $\mathrm{w}$ tym względzie badaczy”2. W sposób bardziej wyczerpujący traktuje Kochankę Szamoty Krystyna Kłosińskaª̨, posługując się krytyką fantazmatyczną zaprojektowaną przez Marię Janion oraz psychoanalizą freudowską. Wpisuje ona nowelę Grabińskiego w ramy dyskursu feministycznego, eksponując w zgodzie z mottem utworu, zaczerpniętym przez pisarza z biblijnej Księgi Rodzaju, motyw narodzin kobiety z pragnienia i ciała mężczyzny. Badaczka w błyskotliwy sposób dekonstruuje wpisany w utwór męski fantazmat kobiety i kobiecości, ufundowany na ambiwalencji postaci matki/kochanki - reprezentowanej przez, obecną także w tekście Grabińskiego, mitologiczną figurę Meduzy. Do motywu tego jeszcze powrócę. Niewątpliwą wartością poznawczą wnikliwego szkicu Kłosińskiej jest wszechstronna i dokładna analiza swoistego „scenariusza fantazmatycznego”, który konsekwentnie rozwija się wraz z fabułą noweli. „Przegląda się w nim cała kultura, która tłumiąc niewygodny aspekt męskiego pożądania, kierującego się ku kobiecie «bez twarzy», chce je postrzegać zawsze jako wysublimowane, odgraniczone od «natury», od «zwierzęcości», a także od waginy"4. Sądzę jednak, że interpretacja Kłosińskiej pozostawia pewien, dość obszerny, margines niedookreślenia (tożsamy być może z ramami dyskursu feministycznego), który postaram się wypełnić w tym szkicu.

\section{„Que l’Autre ne jouisse pas de moi!”}

Z perspektywy psychoanalitycznej interpretacji noweli istotne znaczenie wydaje się mieć dokładna analiza osobowości Jerzego Szamoty i określającego ją pragnienia, za sprawą którego rozgrywa się ów fantazmatyczny dramat stanowiący treść utworu Grabińskiego. Zdaniem Hutnikiewicza Szamota reprezentuje typ psychotyczny - dotknięty „obłędem na tle erotycznym”. Diagnoza ta jest jednak, w świetle współczesnej wiedzy psychologicznej, nazbyt uproszczona, by nie powiedzieć błędna. W ujęciu psychoanalizy Lacanowskiej, Szamota reprezentuje w sposób niemal modelowy przypadek nerwicy w jej odmianie obsesyjnej. Jak wiadomo, zaproponowany przez Lacana schemat diagnostyczny „jest nadzwyczaj prosty, zawiera zaledwie trzy podstawowe kategorie: nerwice, psychozy i perwersje" ${ }^{\text {" }}$. Nerwica zaś „wiąże się z wprowadzeniem funkcji ojcowskiej, asymilacją zasadniczej struktury języka, prymatem wątpliwości nad pewnością, znacznym zahamowaniem popędów w przeciwieństwie do ich niepohamowanego realizowania, tendencją do odnajdywania przyjemności raczej w marzeniach niż w bezpośrednich kontaktach seksualnych, mechanizmem wyparcia w odróżnieniu od mechanizmu wykluczenia, powrotem wypartego z wewnątrz w formie przejęzyczeń, czynności pomyłkowych i symptomów...”․ Pośród neuroz Lacan dostrzega dwa podstawowe typy - określane za sprawą relacji podmiot - obiekt (pragnie-

${ }^{2}$ R. Preus, Parapsychologia na usługach literatury. Rzecz o "Kochance Szamoty" Stefana Grabińskiego, [w:] Wyobraźnia stwarzająca. Analizy i interpretacje małych form prozatorskich, red. R. Mielhorski, G. Piotrowski, R. Preus, M. H. Staśkiewicz, Bydgoszcz 1994, s. 27.

${ }^{3}$ K. Kłosińska, Stefana Grabińskiego "Kochanka Szamoty”, czyli o tym, jak mężczyzna rodzi kobietę, [w:] eadem, Fantazmaty. Grabiński - Prus - Zapolska, Katowice 2004.

${ }^{4}$ Ibidem, s. 46.

${ }^{5}$ B. Fink, Kliniczne wprowadzenie do psychoanalizy lacanowskiej. Teoria i praktyka, tłum. Ł. Mokrosiński, Warszawa 2002, s. 113.

6 Ibidem, s. 163. 


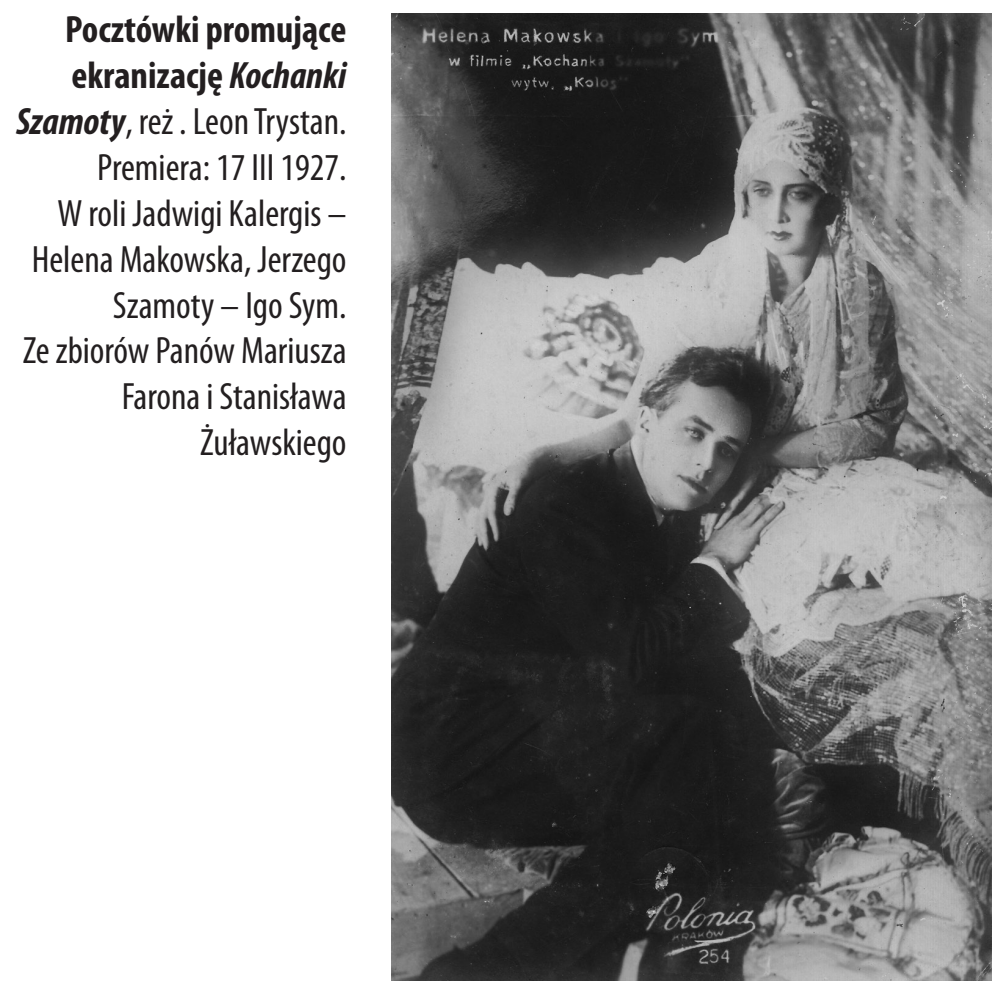

nia): histerię (raczej kobiecą) oraz obsesję (raczej męską)7 ${ }^{7}$. Podmiot obsesyjny „jest sam dla siebie całością", Inny zaś zostaje przezeń zredukowany do obiektu a (l’objet petit a) - „obiektu, który w kobiecie widzi, i którego od niej chce”. W konsekwencji zaś mężczyzna obsesyjny „,wchodzi w relację ze swoim obiektem $a$, neutralizując obecność kobiety” ${ }^{10}$. Taka relacja określa w sposób zasadniczy charakter seksualności podmiotu obsesyjnego, która „w gruncie rzeczy, ma charakter masturbacyjny, Inny jest unicestwiony” ${ }^{11}$. Dzieje się tak dlatego, że - zdaniem Lacana - człowiek obsesyjny nie jest w stanie uwolnić się od realizowania nieświadomej strategii: Que l'Autre ne jouisse pas de moi! (Oby Inny nigdy się mną nie rozkoszował! $)^{12}$, określającej jego pozycję wobec Innego (i jego jouissance, rozkoszy).

Kim zatem jest Jerzy Szamota - podmiot obsesyjny? Przede wszystkim kochankiem swego fantazmatu, kobiety zredukowanej do obiektu pragnienia, źródła seksualnej rozkoszy, której doświadczać może tylko sam Jerzy, nie płacąc za to ceny w postaci rozkoszy Innego (kobiety). Nie może zatem dziwić odkrycie przez Szamotę podobieństwa znamion, ani fakt, że to on krwawi po ukłuciu Jadwigi szpilką. Jadwiga Kalergis jest wszak ostatecznie li tylko masturbacyjną fantazją Jerzego - symptomem jego obsesji, który w finałowej scenie ujawnia się obscenicznie pod postacią „powrotu wypartego” - obiektu $a$. Interpretacja

\footnotetext{
7 Ów podział płciowy nerwic nie ma jednak charakteru kategorycznego.

8 B. Fink, op. cit., s. 177.

9 Ibidem, s. 184.

${ }^{10}$ Ibidem.

11 Ibidem, s. 186.

12 Ibidem, s. 374-375.
} 

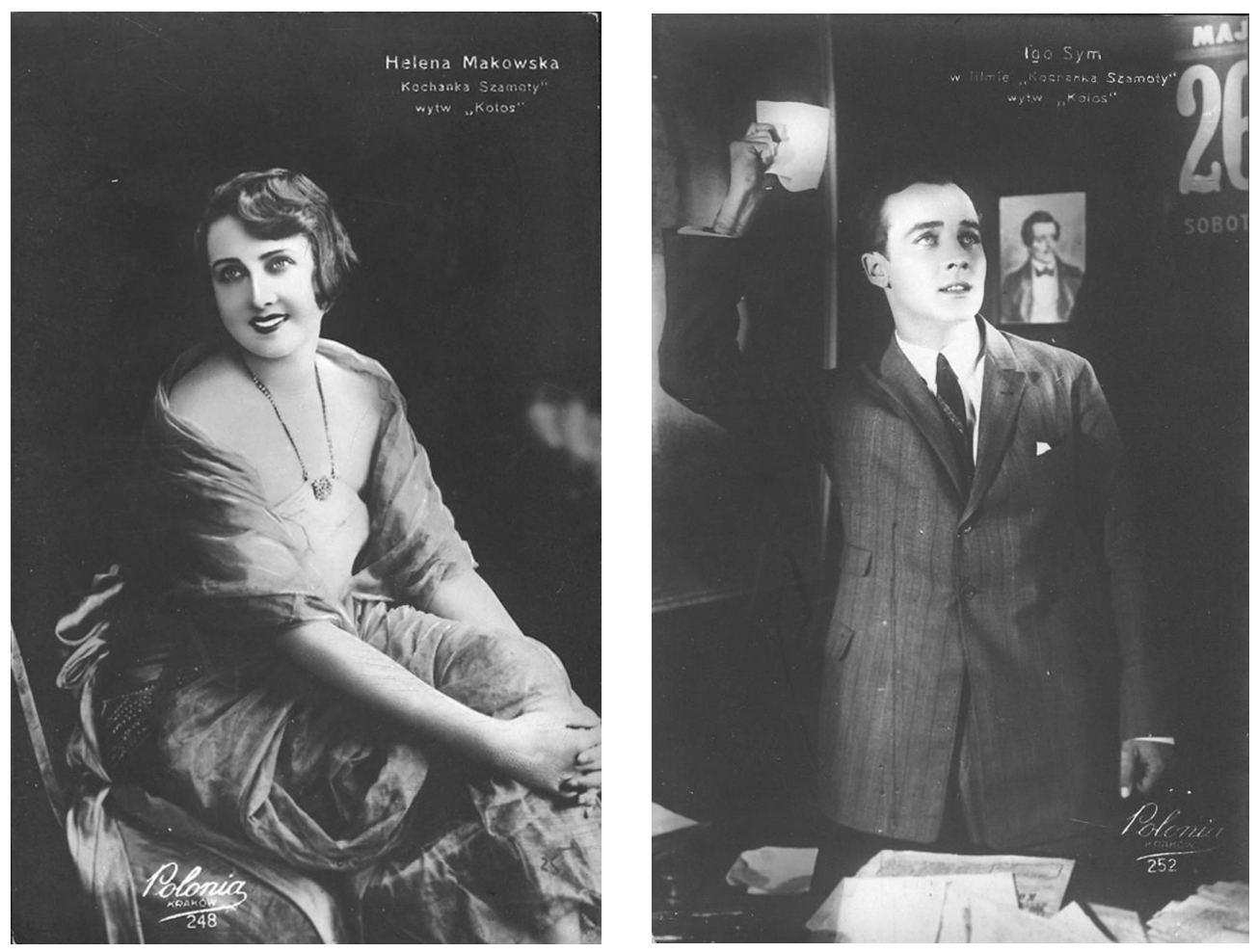

taka mieści się zresztą dobrze w ramach Lacanowskiej koncepcji kobiecości, wedle której: „«Kobieta nie istnieje», czy też «Kobieta jest nie-cała»"13, okazując się ostatecznie symptomem mężczyzny. Tak postrzeganej kobiecości Lacan nadał „teoretyczną postać miejsca grozy, przedstawial ją jako ziejącą czeluść, jako «rzecz» wyposażoną w cechę ekstremalnej oralności i naturę zniekształcającą ją nie do poznania: rzecz realną, heterologię" ${ }^{14}$. Wszystkie te cechy posiada z pewnością kochanka Szamoty. Ale to jeszcze nie wszystko...

Uwagę czytelnika-interpretatora Kochanki Szamoty przykuwa w sposób oczywisty dramatyczny proces systematycznego „znikania” Jadwigi Kalergis, jej stopniowego redukowania - jako seksualnego fantazmatu bohatera - do finałowego korpusu eksponującego li tylko pierwszorzędne cechy płciowe. Umyka natomiast obserwacji równie znamienna redukcja postaci samego Szamoty, relacjonowana przezeń już po ostatniej schadzce: „Posiwiałem przez jedną noc. Znajomi nie poznają mnie na ulicy. Podobno leżałem przez tydzień bez pamięci i bredziłem w malignie. Dziś dopiero wyszedłem po raz pierwszy z domu. Chwieję się jak starzec i wspieram na lasce. Okropny koniec!...” (N, s. 405). Wydaje się więc, że „znikaniu” fantazmatu Kalergis towarzyszy analogiczne „znikanie” Jerzego Szamoty, wynikające $z$ utraty sił witalnych podtrzymywanych przez samo pragnienie ${ }^{15}$. Sytuacja ta całkiem dobrze wpisuje się w Lacanowski model relacji seksualnej między mężczyzną a kobietą -

\footnotetext{
13 E. Roudinesco, Jacques Lacan. Jego życie i myśl, tłum. R. Reszke, Warszawa 2005, s. 525.

14 Ibidem, s. 526.

15 Motyw pozbawiania mężczyzny sił witalnych przez demoniczną kochankę nie jest obcy twórczości Grabińskiego, powracając także w „wampirycznej” noweli W domu Sary.
} 
postrzeganą właśnie jako „symptom mężczyzny”. Wbrew potocznej recepcji tego pojęcia, podkreślającej całkowitą zależność kobiety od mężczyzny, relacja ta ma również swą drugą stronę: „Jeżeli to bowiem symptom zapewnia spójność podmiotu, jego rozproszenie zniszczyłoby tę spójność, a zatem podmiot by zniknął. Teza, że «kobieta jest symptomem mężczyzny», oznacza w takim razie, że mężczyzna istnieje tylko o tyle, o ile kobieta nadaje mu spójność. Innymi słowy, jego egzystencja zależy od kobiety" ${ }^{16}$. Jak wolno przypuszczać, to właśnie przydarza się kochankowi, który swą egzystencję powiązał całkowicie z obiektem swego pragnienia - Jadwigą Kalergis. Jej zniknięcie i wygaśnięcie pragnienia prowadzi do rozpadu osobowości kochanka - zniknięcia męskiego podmiotu.

Czy proponowane w tym miejscu odczytanie noweli Grabińskiego można uznać za trafne i w pełni uprawnione? Można to sprawdzić, pytając, czy ma ono zdolność sfunkcjonalizowania maksymalnie dużej liczby składników badanego utworu ${ }^{17}$. A zatem ... Interpretacji Krystyny Kłosińskiej nie umyka pewien mitologiczny detal wkomponowany starannie w strukturę artystyczną tekstu Grabińskiego. Jest nim obraz Gorgony - „grecka pawęż z wizerunkiem Meduzy" (N, s. 398) - przykuwający uwagę i więżący spojrzenie Szamoty $\mathrm{w}$ chwilach poprzedzających miłosne zbliżenie. Meduza hipnotyzuje bohatera, obezwładnia go, uruchamiając władze fantasmagorii i zwiastuje nadejście Kalergis. Kłosińska słusznie odczytuje fantazmatyczną moc „petryfikującego wolę bohatera” wizerunku, wpisując ją w kontekst psychoanalityczny za sprawą przywołania szkicu Freuda Głowa Meduzy, w którym wiąże on ów obraz mitologiczny z (męskim) doświadczeniem odsłonięcia kobiecych narządów seksualnych. Zdaniem Kłosińskiej w noweli Grabińskiego fantazmat ten w powiązaniu z finałowym obrazem „kobiecego kadłuba” może spełniać paradoksalną funkcję fantazmatu „wyzwalającego z fantazjowania"18. Czy jednak na pewno? I jaki związek ma ten motyw z proponowaną tu interpretacją?

Podczas swego seminarium zatytułowanego Le moi dans la théorie de Freud et dans la technique de la psychanalyse (1954-1955) Jacques Lacan, odwołując się do słynnego Freudowskiego snu „o zastrzyku Irmy”, dokonał dość zaskakującej reinterpretacji klasycznej wykładni owego marzenia sennego. W kluczowym fragmencie tego snu Freud analityk zagląda do gardła swej pacjentki, Irmy, by odkryć w nim „dużą białą plamę” oraz „osobliwe pomarszczone twory, utworzone najwyraźniej na podobieństwo małżowin nosowych, rozległe białoszare strupy"19, co wiedzie go w późniejszej analizie ku skojarzeniom do własnego stanu zdrowia oraz poczuciu winy wobec (innej) źle leczonej pacjentki. Otóż Lacan proponuje zgoła odmienną interpretację tego motywu sennego, „utożsamiając «otwarte usta» Irmy z ziejącą czeluścią narządów płciowych, z których wyłania się przeraźliwy czerep Meduzy"20. Warto odnieść tę zastanawiającą interpretację do sytuacji przedstawionej w noweli Grabińskiego, w której zniewalający obraz Meduzy wydaje się ściśle powiązany nie tylko z pojawianiem się fantazmatycznej kochanki, ale również z finałową sekwencją obscenicznego obnażenia się kobiecości w postaci zredukowanej do cielesnego kadłuba

\footnotetext{
${ }^{16}$ T. Myers, Slavoj Žižek, tłum. J. Kutyła, [w:] Žižek. Przewodnik Krytyki Politycznej, Warszawa 2009, s. 122.

17 Zob. H. Markiewicz, Interpretacja semantyczna dzieł literackich, [w:] idem, Wymiary dzieła literackiego, Kraków 1984, s. 186

${ }^{18}$ K. Kłosińska, op. cit., s. 47.

19 S. Freud, Objaśnianie marzeń sennych, tłum. R. Reszke, Warszawa 1996, s. 107.

${ }^{20}$ E. Roudinesco, op. cit., s. 526. Na temat tej Lacanowskiej wykładni snu Freuda zob. także S. Morgan, The Dream of Psychoanalysis: Irma's Dream, Some Commentaries, and a Contemplation of its Navel, "British Journal of Psychotherapy”, Vol. 12, Issue 2, December 1995; Reading Seminars I and II: Lacan's Return to Freud, ed. B. Fink, M. Jaanus, R. Feldstein, State University of New York Press 1996.
} 
eksponującego genitalia. Znamienne jest przy tym, że podczas ostatnich schadzek Szamota świadomie i celowo unika niepokojącego „spojrzenia Meduzy”, które odbija jego własne spojrzenie: „cały skupiłem się w jednym świetlanym punkcie, w miotającym pioruny blasków oku wężowłosej Gorgony!” (N, s. 398). Warto zauważyć, że ten opis doświadczenia Szamoty dość dokładnie odpowiada Lacanowskiej definicji spojrzenia, które zdaniem francuskiego psychoanalityka „istnieje u p r z e d n i o wobec podmiotu, który «oglądany ze wszystkich stron» zdaje się zaledwie «plamą» w «spektaklu świata». Tak umiejscowiony podmiot często odczuwa spojrzenie jako zagrożenie, jako skierowane doń pytanie. [...] A zatem podmiot został wystawiony na spojrzenie przedmiotu, jest fotografowany przez jego światło, kadrowany przez jego spojrzenie"21. I to właśnie spojrzenie przedmiotu ma charakter traumatyzujący ${ }^{22}$.

W noweli Grabińskiego spojrzenie Meduzy, którego unika Szamota, antycypuje w sposób oczywisty i nieunikniony spojrzenie, jakie rzuca na bohatera owa traumatyczna Rzecz objawiająca się w finale utworu pod postacią kobiecego korpusu, w którym przecież bohater również „skupił się cały” jak wcześniej w spojrzeniu Gorgony. W ten sposób - ukazując się w całej swej grozie - Realne ujawnia się jako głowa Meduzy raz jeszcze spoglądająca na bohatera wprost $\mathrm{z}$ wnętrza kobiecego łona, obezwładniając go i przerażając. Trauma powraca, a erotyczny dramat zostaje domknięty. W takim kontekście seksualna przygoda Jerzego Szamoty wiedzie go prostą drogą ku konfrontacji z kobiecością doświadczaną jako element porządku Realnego - Rzeczą (das Ding) ${ }^{23}$, która przeraża, „obnażając się bezwstydnie” (N, s. 406) jako obiekt pragnienia. Reakcja kochanka nie pozostawia zresztą w tej kwestii najmniejszych wątpliwości: „Z okrzykiem grozy wypadłem z sypialni ...” (N, s. 406). Lacanowska interpretacja tej sekwencji fabularnej w powiązaniu z kontekstem mitologicznym nie wpisuje się wprawdzie zbyt dobrze w proponowany przez Kłosińską - podszyty freudyzmem - dyskurs feministyczny, podtrzymując w pewnym stopniu fantazmat kobiety jako „symptomu mężczyzny”, postrzegany niekiedy jako psychoanalityczne dziedzictwo modernistycznej mizoginii ${ }^{24}$. Pozwala ona jednak wyjaśnić niewątpliwą traumę, jaka towarzyszy konfrontacji Szamoty z Realnym - obiektem pragnienia ${ }^{25}$.

${ }^{21}$ H. Foster, Powrót Realnego. Awangarda u schyłku XX wieku, tłum. M. Borowski, M. Sugiera, Kraków 2010. W zaznaczonych miejscach Foster cytuje tekst Lacana pochodzący z tomu Le Seminaire de Jasques Lacan, Livre XI, Editions du Seuil, Paris 1973.

22 Poczucie bycia obserwowanym przez Rzecz (das Ding) traumatyzuje podmiot, podobnie jak przyciągająco-odpychające spojrzenie Innego go histeryzuje. Spojrzenie rzucane przez Rzecz na podmiot zwiastuje traumę także w innych opowieściach grozy, np. w znanym utworze Henry'ego Jamesa W kleszczach lęku. Pisałem o tym obszernie w książce Literatura i nierozum. Antropologia fantastyki grozy, Toruń 2009, s. 210-212.

${ }^{23}$ Kobietę jako Rzecz - efekt sublimacji i swoisty "symptom mężczyzny" tak charakteryzuje, w ujęciu Lacanowskim, Slavoj Žižek: „Miejsce Damy-Rzeczy jest pierwotnie puste: funkcjonuje ono na zasadzie «czarnej dziury», wokół której ustrukturowane jest pragnienie podmiotu". S. Žižek, Miłość dworska, czyli kobieta jako Rzecz, tłum. T. Zarębski, [w:] Žižek, s. 269.

${ }^{24} \mathrm{O}$ feministycznych polemikach z Lacanowskimi koncepcjami kobiecości zob. np. E. Roudinesco, op. cit., s. 519-520. Podstawowe sprzeczności między psychoanalizą lacanowską a modernistyczną mizoginią wywiedzioną z filozoficznego traktatu Otto Weiningera Płeć $i$ charakter omawia Tony Myers w szkicu Slavoj Žižek, [w:] Žižek, s. 112-123. Rzecz jasna sam utwór Grabińskiego wpisuje się w ten nurt mizoginii, choć jest to, doprawdy, mizoginia fatalistyczna i podszyta rozpaczą.

${ }^{25}$ Konfrontacji tej nieodmiennie towarzyszy poczucie grozy, które wyłania się z doświadczenia „niesamowitego" (das Unheimliche), a więc wypartego, które powraca. Zob. S. Freud, Niesamowite, [w:] idem, Pisma psychologiczne, tłum. R. Reszke, Warszawa 1997. W dyskursie Lacanowskim poczucie niesamowitości tożsame jest $z$ doświadczeniem Realnego, które powraca w porządku Symbolicznym. Zob. D. Brzostek, op. cit., s. $115-142$. 


\section{Ilustracja do noweli Engramy Szatery, „Naokoło Świata” 1926, nr 28, rys. J. Kożuchowski}

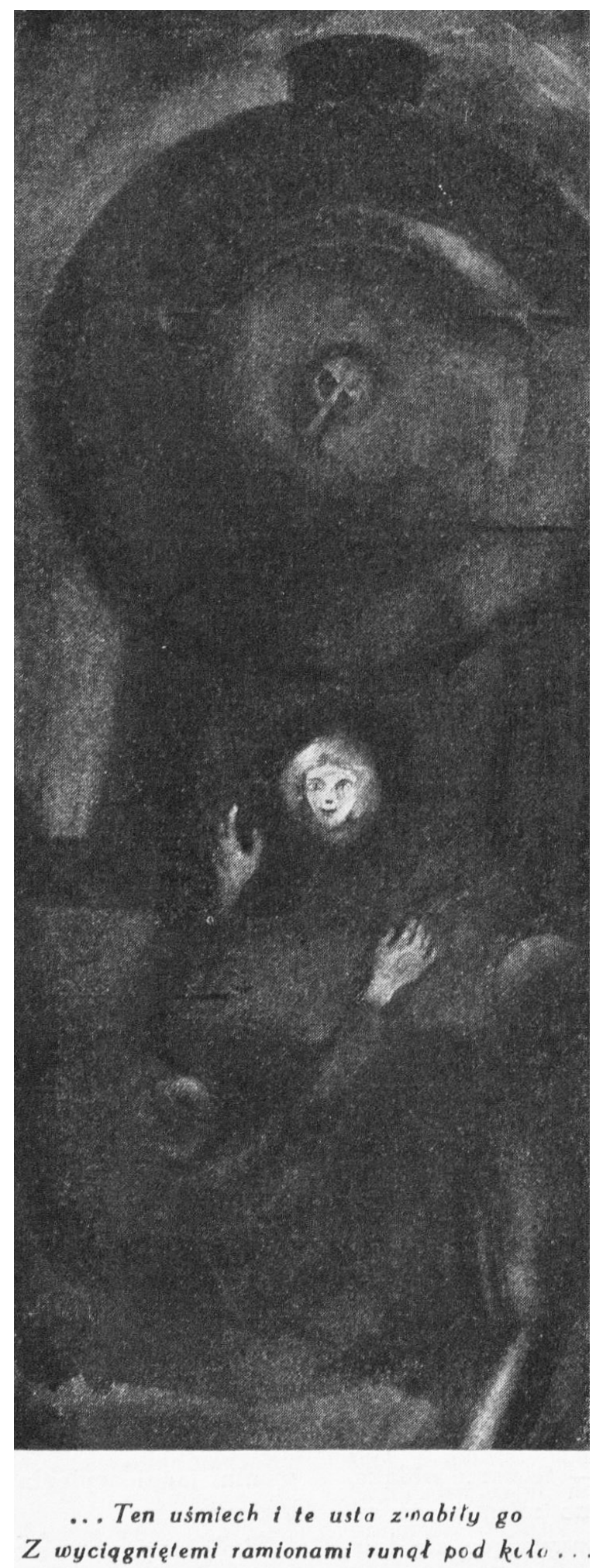


Czy zatem Kochanka Szamoty okazuje się przede wszystkim przypowieścią o niedoli męskiej kondycji psychoseksualnej? Zapewne tak, ale jest co najmniej równie interesująca $\mathrm{z}$ innego powodu. I to nie tylko jako efektowne, literackie exemplum Lacanowskiego dyskursu psychoanalitycznego. Choć bowiem mieści się doskonale w złożonym uniwersum znaków i obrazów, pojęć i modelowych narracji francuskiego myśliciela, to przecież jednak nie da się jej traktować jako „historii przypadku” ujętego w estetyczne ramy literackiej fikcji, ani też jako zapoznanej zapowiedzi koncepcji Lacana. Ciekawsza jest chyba jako świadectwo tego, w jaki sposób literacka fantastyka grozy, nie całkiem świadomie, umieszczała w polu refleksji psychopatologicznej zjawiska usytuowane w domenie „niemożliwego” (parapsychologii, przesądu) - wymykającego się poznaniu, poddając je - jeśli nie diagnozie (brak jej wszak teorii!) - to z pewnością opisowi oraz wiwisekcji i stając się w ten sposób, zgodnie z sugestiami Jeana Le Guenneca, „literacką psychoanalizą nierozumu”26.

${ }^{26}$ Zob. J. Le Guennec, Raison et déraison dans le récit fantastique au XIXe siècle, Paris 2003. 